\title{
A INSTITUCIONALIZACIÓN DO DISCURSO LITERARIO GALEGO (1975-1990)'
}

\author{
Xoán Gonæálè-Millán \\ (ity University of New York
}

\section{Análise institucional.}

A aplicación do paradligma institucional á análise da producción literaria subliña a relevancia dunha serie de factores que normalmente son relegados e incluso silenciaclos por outros modelos críticos. A súa operatividade resulta especialmente eficaz no contexto de culturas marxinais e periféricas, nas que se observa unha configuración deficitaria, debida en gran parte a relacións de dependencia sociocultural, política c económica. A análise instilucional cuestiona especialnente a existencia dunha hipotética entidade literatia en abstracto, e propón como ámbito de estudio as prácticas discursivas específicas que operan á ve\% sobre a linguaxe e sobre o imaxinario. Un paradigma semellante obstaculiza tecturas excesivamente idealizaclas da producción litcraria, e facilita a iclentificación das prácticas concretas que a clelinen en relación cos outros espacios discursivos (Bennet1, 1990).

Para que un cliscurso funcione como tal é necesaria a intervención institucional dun me-

I.- Nota: as referencias ás publicacións de fiecuente periodicielate (xornais, semanarios ou revistas de aparición mensual) danse no mesmo lexto, para evitar un exceso (le información na biblingrafía final. As siglas ulilizadas correspóndense ás seguintes publicacions:

AN'T: A Nosia 'Terria

C(i: El Correo (iallego

D)-16: Diario 16 de Cialicia

FV: Falro de Vigo

V(i: Voz de Galicia 
ladiscurso que lexitime o seu comportamento. Ambolos dlous, o discurso e o metadiscurso, forman parte dun espacio social, estructurado segundo principios de institucionalización que tenden a lexitmar a súa arbitrariedade. Fsta hipótese inicial recpuire traballar cunlal concepción do texto literario semellante á que propón R. Fowler en A Dictionary of Modern Critical Terms:

Discourse theory conceives of the literary work als an instance of the historically variable institution of literature, an institution which mediates relations between writer and reader in different ways at different limes, and in so doing, echoes, transforms, or challenges the uneven distribution of power within society (1990: 66).

Ĺ necesario engadir. sobre todlo no contexto de sociedades marxinais, que os axentes institucionais, que teñen como obxectivo prioritalio ganantir a cfectividade da práctica discursiva mediante a súa lexitimación como práctica social e a elaboración dunha ortodoxia especílica. non abranguen a totaliclade clas prácticas literatrias dunha sociedade nun período definido, senón aquelas que, segundo Peter Bürger, exereen determinadas funcións:

The literary institution serves special purposes in the social system als a whole; it develops an aesthetic cocle lunctioning als a boundary againts other literary praclices; it claims an unlimited validity (it is the institution which determines what in a given period is regarded as literature). The normative level is at the center of a thus defined concept of institution, because it determines the patterns of behavior both of the producers and the recipients. | |... Thus literary debates are of great importance: they may be regarded als struggles to establish the norms of the literary institution. We may interpret these struggles as the often contradictory expression of social conflicts (1983: 422).

C.J. van Rees ofrece un inventario máis concreto, no que figuran «organizations involved in the material production and distribution of literature $\mid . .$. |: councils which advise national and local authorities $|. .$.$| and the somewhat loosely organised groups of people who seek$ to specify and propagate conceptions of literature» (1983: 292). Fistes axentes especílicos aspiran a delimitar un espacio autónomo e autorregulado, fronte a outros axemtes que, dentro ou fora do mesmo ámbito discursivo, intentan impoñer a súal propia normativa'. (O mesmo C.J. van Ress propón como punto de partidal parta unha análise do comportamento dos axentes institucionais o estudio das estratexias utilizatlas pala definir e clasilicar os diversos sistemas de codificación literaria:

Texts owe their literary or aestethic $\mid . .$. | character to the fact that specific social groups and institutions subject them to a vallorisation process; instrumental to this process are the conceptions of literature adopted by these groups and institutions. A conception of literature is a sel of normative statements on the properties which texts ought to possess to be reckoned as literary and on the funclion to be assigned to literalure (1983: 286).

Privilexiar a atribución de calidade como o enfoxpe metodolóxico munha análise institucional da producción literaria pode resultar ma misión de varios dos seus aspectos relevintes, porque as institucións non teñen como lin exclusive a definición normaliva do cue debe

2.- Na análise institucional convén distinguir, como propón Mare Angenol, entre a institución propia-

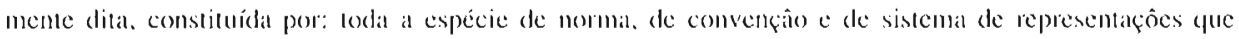
regem a ordem social e mantêm nomeadamente o modo de produçấo e as divisôes de classe que dele decorrem, $|\ldots|$ |c o aparello, representado polos] tipos de poder (poderes repressivos "MDBB() materiais "MIDNM" e poderes sinbólicos) que asseguram a mamutençầo, a reproduçî́o e a adaptaçââ relativa da própria instituçäo (1984: 38-39). 
ser un texto literario, se ben é certo que neste proceso invisten moitas das súas cnerxías. Ademais, mona lectura institucionalista do fenómeno literario debe responder á cuestión sempre aberta da creación textual. se quere evitar interpretacións sesgadas on hipertrofiadas, como recoñece Alain Viala na seguinte descripción:

I a création textuelle s'accomplit à travers un ensemble de primes. Prisme de la langue et de la psychè de l’auteur. mais aussi primes constitués par la structure même du champ el. all sein de celui-ci. par les coles particuliers de chaque institution el par les relations des institutions entre elles. Prismes, aussi, des compétences el attentes des lecteurs, lesquels subissent à leur tour les effets du eode des genres, des répulations établies par les criticues, des habitudes de penséc acepuises au cours de leur formation (1985: 10).

A valoración literaria dumha manilestación discursiva deteminada non se esgota na súa asignación estética; noutras palabras, a importancia asignada a este valor non debe silencian outas propiedales que calquera sociedade, num momento determinado, pode considerar retevantes para definir un texto como litcrario. Incluso en situacións nas que se experimenta un alto grao de coincidencia conceptual en cante a cue debe ser un texto literario, pode haber ostensibles variacions na forma como é utilizado polos diversos grupos sociais: un mesmo lexto ofrece múliples, é ás veces contradictorias, lecturas se é sometide a procesos hermenéuticos distintos (a obra poética de Rosalía de Caston como exemplo emblemático da literaltura galcgal)'.

Estas consideracións iniciass suxieren a necesidade de superar unha visión estática e monopolista do funcionamento dess axentes que interveñen na institucionalización literaria. Todat institución, por definición, é continxente e conflictiva. porque intenta presentar como natural a inevitable arbitrariedacle (la súa normativa. No caso do espacio literario, e (las prácticas artísticas en xeral, as tensións tradúcense na oposición entre a ortodoxia oficial e a(s) heterodoxia(s) marxinais. e máis concrelamente nas dispares canonizacións de textos e xéneros, e, en ciltima inslancia, na definición mesma do que debe entenclesse por literaturat.

() alto nivel de conflictividade interna do sistema literario galego, e a súa institucionalización deficitaria, débense en glan parte á súa dobre conclición de malxinal e periférical, e á

3.- Segundo J. Dubois: l'institution délinit, à chaque étape de son histoire, des lectures (c'est-àdire des significations) et modes de lecture. Elle définit donc des codes pour l'usager, el à travers ces codes passemt les luttes pour la définition du légitime es la délention du pouvoir symbolique (1978: 127).

lista hipótese de Dubois subliña un aspecto importante no proceso de institucionalización do sistema literario galego. Se cada período recompón. como parte da súa transformación, a lóxica dos diversos modos de recepción. incorporando novos códigos que se constitúen como resultado dos diversos mecanismos de producción simbólica colectiva. non debe estrañar a crecente diversificación de interpretacións a que está

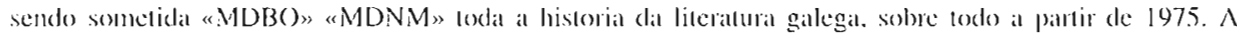
décarda dos 80 permite observar cambios profundos nos máis diversos aspecelos da institucionalización do feito literario galego, dende a intervención de novos axentes ala a delinición mesma do que é (pode. ou (lebe ser) un texto literario.

4.- Clément Moisan defende esta visión conflictiva da historia da instifución literaria, que: serail une fafon de voir comment se constiment dans le lemps les regles. les nomes el les codes de production; les modes de diffusion ou de réception des produits littéraires et enfin les instances de reconnaissance te de sanction des mêmes produits. At lous ces niveaux. c'est l'une sotte de combat, de rivaliés des instances dont vit l"lnstitution, call celle-ci est faire d'unc série d’agents conservalteurs el perturbateurs à la fois (1987: 1.58).

Hai (fue advertir, sen embargo, contrat os perigos dunha hipotética relación directal entre o grace de continxencia instilucional e a inestabilidade dos xéneros ou da mesma conliguración do canon. 


\section{XOÁN GONLÁL,I:\%MILLÁN}

incidencia dos diversos movementos sociais, políticos e culturais, gue utilizan a litcratura como un discurso social privilexiado para formular propostas reivindicativas, é dicir, antiinslitucionais". Este contexto permite entender a duplicación conflictiva de institucións funcionalmente homologables que caracteriza o panorama cultural galego, sobre todo a partir de 1975. (Os enfrentamentos institucionais danse en dous ámbitos distintos, pero mutuamente implicados: (lunha bancla o conllicto multisecular entrc as institucions do goberno central e as institucións públicas ou privadas galegas; doutra. a rivalidade entre as institucións galegas que intentan facerse eo monopolio da recuperación cultural do país".

O carácter inorgánico e anti-institucional de moitos axentes colectivos galegos, sobic todo no ámbito da producción cultural, é reflexo dos scrios obstáculos cos que se enfientan para intervir (le forma autónoma e efectiva na formulación e execución dunha determinada nomativa. As pregumbas son inevitables: ¿Como asignar un valor a un texto concreto canclo a mesma cultura á que pertence carece do prestixio social necesario para facer utilizable este valor? E se a cultura está privada desal aura necesaria para funcionar como tal cultura, ¿como pode intervir con efectividade unha institución que actúa en nome desa mesma cultura? As distintas respostas a esta complexa situación constitúen a crónica do aconteciclo a nivel institucional na consolidación da autonomía do discurso literario galego a partir de 1975.

\section{Autonomía discursiva.}

O sistema literario galego, as súas relacións interxenéricas, así como os intentos de canonización existentes, e as conseguintes propostas normativas do feito literario, aportan, como veremos, elementos de xuízo valiosos de cara a documentar, sobre todo a partir de 1975, a crecente autonomía do discurso literario galego, e o carácter irreversible deste proceso. A consolidación e expansión das diversas modalidades narrativas, e a súa canonización como o xénero predilecto do mundo editorial galego, permiten deducir unha dinámica cultural cada vé máis complexa, con claras implicacións para o munclo editorial e especialmente para o discurso literario. En canto á poesía deste mesmo período, a diversidade de rexistros, e o culturalismo de que é acusada, poden ser interpretados como indicadores dun esforzo do poela galego por consolidar unha linguaxe literaria máis autónoma. Xunto a cstas trasnformacións xenćricas detéctanse cambios noutros ámbitos do discurso literario galego: a lenta consolidación do mundo editorial; a creación de organizacións profesionais de escritores; a entrada da literatura galega no sistema educativo; as crecentes subvencións oficiais á creación literaria; a aparición (le revistas especializadas; $\mathrm{c}$ un corpus crecente de bibliogralía crítica.

F́ fundamental, sobre todo en situacións de marxinalidade, ter en conta a interacción entre as diversas áreas da producción simbólica, e as dificultacles que dela se derivan, en parte

5.- () concepto de "sistema literario deficitario». proposto por I. Even-7.ollat nun dess seus traballos sobre a teoría des polisistemas literarios, está basade no parámetro ou principio xeral de insuficiencia: "This ciln be batsed on the notion of system optimun $|\ldots|$ ats an indispensable implication of the polysystem hypothesis. The concept of optimum is a hypothesis about the the optimal (1) polysystem structure (i.c.. sets of hierarchical relations) as well as the optimal structure of (2) the repertoire(s) considered necessary for those mechanisms of produclion and consumption without which a system cannol function" (1990): 81). Noutras palabras, todo esfor\% institucional basea is súa estratexia nun obxectivo ben definislo: a permanente busca (lo nivel óptimo parat o (lesenvolvemento do sistema literario.

6.- Peter Bürger simala no taballo xa citack) (1983) a coexistencia, obviamente difícil e inestable, de varias institucións que pretenden facerse co control do proceso de lexitimación da producción literaria. 
debido ás múltiples funcións gue o discurso literario está obrigado a realizar. $\Lambda$ partir de 1975, e sobre tocio na décadla seguinte, a sociedade galega anosa un dinamismo de expansión e diversificación que semella ter unha incidencia directa na aparición de fómulas e propostas (jue permiten falar dunha crecente autonomía dos espacios discursivos. O literario, no que se inclúe todo o conxunto de instilucións que lexitiman a súia actividade", é o que máis dificultades encontra no proceso de crecente autonomía que caracteriza a producción simbólical da sociedade galega actual. As razóns deste feito hai que localizalas na inevitable función reivindicativa cue os textos literarios se viron obrigados a desempeñalr pola deficiencia e pobre articulación dos demáis espacios discursivos". No caso do sistema literario galego percíbese un paulatino distanciamento do discurso literario con respecto a determinadas posicións ideolóxicas nacionalistas". O abandono de determinadas funcións e a incorporación doutras novals caracteriza a producción literaria galega actual, e ó mesmo tempo permite conxcturar hipóteses de cara á súa crecente autonomía instilucional. ou, o que é o mesmo, a redefincición da súa posición no conxunto dos discursos sociais que actúan na sociedade galegal.

O concepto de autonomía aplicado ó espacio literario galcgo esixe unha aclatación importante: individualmente, o escritor non ten adquiriclo a condición de profesionalidade que lle permita vivir da cscritura, como demostra a necesidade de compartir o seu oficio de escritor con outras ocupacións economicamente máis rendibles. $\Lambda$ cmancipación do espacio literario, ou polo menos a súa crecente autonomía, tradúcese nunha liberación do escritor como ente colectivo; ć a súa maxe social a que aparece renovada por esta dispersión do control

7.- France Vernier ofrece un inventario moi útil palla unha análise institucional dos distintos aspectos que definen a actividade do discurso litwario: les conditions d'émergence des lextes. leur production, l'édition. la diffusion, les institutions scolaires el universitaires, les conditions dapprentissage de la langue. la lecture, les différentes inslances législatives en ec domaine, comme les académies, les prix littéraires, les reveses, la détinition du domaine culturel et des corpus littéraires, ete. sans que. pour ke moment, l'on décide yu’un de ees éléments est premier par rapporl anx autres, ni même que l’un d'entre eux puisse être premier (1977: 38)

8.- Así o recoñece Ralfacl ('hacón, sintetizando un longo proceso histórico da literatulal galega: «L al literatura aparece ligada a todas lass formas de reivindicación que en Galicia se dan tanto culturales, sociales como políticals" (Camp) de l'Arpa, 75, 1980). En A Nosa Terra (37.5. 16-2-1989) pode letse un articulo firmado por $\mathrm{M}$ |anuell $\mathrm{V} /$ eigal, no yue se analizan determinados aspectos da cultura galegal. () lítulo mesmo resume perfectamente o contide do traballo: "i.Debe ser a nosal cultura universal. urbana. apolíticat. erudita e nomal'?" A relevancia deste traballo resiele nas reterencials que nel se fan á novela galega dos 8). Este (lato (emostra que o (liscurso literario, especialmente o representado polos novelistas máis novos. segue funcionando ánda ó longo da década dos 80 como unha referencia inevitable para entender ou charilicar aspectos básicos da cultura galega.

lsta hipertrofia social do discurso literario é un fenómeno compartido por outras culturas, como amosa a distribución temática das produccións editoriais. J.M. latsigabaster ofrece os seguintes datos parra o mun(d) vasco: "Intre 1960 y 1975 la literatma representa el $41 \%$ de los libros publicados en cuskera. In 1986, el 24\%. Fisto quiere decir que son cada ve\% más nuneroses los sectores temáticos a los que está llegando el libro vasco. [... l la literatura constituye hoy [1986] una parte porcentualmente nomalizada de los lextos cue se producen en cuskera” (I.etras españolas, 1976-1986, 286). 1: Miguel Prat, nun allículo controversial sobre a situación da literatura catalanta. baixo o título de "Litcrattura caltalana posinormal», comenta ironicamente que uen un país cuya seña de identidad cultural última es la lengua |... la literalura debe correr forzosamente con todos los galstos de representación" (Quimera, 5I, [sen (latal). 9.- Deste fenómeno dá testemuña a crítica literaria feita dende unha deleminada posición nacionalista, representada de forma emblemática polos traballos de F. Rodrígue\% sobre todo (1990), para (fuen as últimas tendencias da literatura galega están caracterizadas por un crecente falscamento con respecto ós vieiros que debería seguir. 


\section{XOÁN (IONLÁLLZL-MII.LÁN}

(liscursivo, é pola conseguinte diversilicación das institucións que presenden lexitimar, cada unha desde perspectivas distintas, e incluso opostas, a súa popta imaxe do discurso literario. A imposibilidade da dedicación exclusiva á literatura non desminte, pois, o proceso parello de crecente automomía do espacio literario. coas consecuencias que deste feito se derivan para a imaxe social do escritor.

A pesalr das reaccións dunha crítica uraldical» que só admite como galego o rexıo que problematiza determinadas representacións (lo mundo sociocconómico galego, a "razón social» da literatura a partir de 1975, e sobere todo durante a década (bos 80). tense diversificaldo en correspondencia coa crecente complexidade do espacio discursivo galego. (Os excritores coalíganse para instituír asociacións yue non só poiclan responder ás razóns sociais que tradicionalmente se lle viñan asignando ó discurso literario galego (reivindicación, crítica. proxección nacionalista), senón tamén ás súas novas dimensións (profesionaliaación, mercantilización, diversificación xenérica e subxenéricar. etc.). (óa consolidación do postrancpuismo a ambigiedade que tiña caracterizado ó campo literario galego nas clécadas anteriores (ausencia, deficiencia on imprecisión na delimilación de decteminados xéneros. imposibilidade da profesionalización do escritor, etc.) vai transformándose nunha crecente autonomía institucional $1 "$.

«MIDNM»As acusacións ó crecente «culturalismo»» da litcratura que se escribe en galego) nesta década dan constancia indirecta desta nova dimensión do feito literario galego. Carlos Casares, xal en 1977, atrevíase a afirmar que uponcos son xa os que se deixan intimidar polas coaccións do terrorismo intelectual. Neste senso, palabras como 'intimista' on "culturalista” xa non som recibiclos como acusaciónsy (Téma, 3. 30/12/1976-6/1/1977). A década dos 80 encargariate de (lesmentir este optimismo inicial. Nunla encuisa realizarla en 1987. e publicada en A Nosa l'erra (328, 3-12-1987), destacados representantes da cultura galega ofiecían os seus comentarios a partir (la seguinte pregunta: "QQue mudou nestes (le\% anos 11977 87]?». Manuel María, na súa condición de escritor, emitía o seguinte balance: "a |galega| é unha poesía descomprometida totalmente coa vida real e comprometicla coa vicla dos libros. |...| Déronse influencias da poesía cultural e dese culturalismo que está moi de moda». $\wedge$ vixencia deste criterio valorativo segue en active a limais da clécada, como amosa o comentario de Pilar Pallatés, (que se laia nas páxinas da mesma publicación galega de (que una literalura galegal hai moito culturalismo gratuito» (397. 27-7-1989). (Jns meses antes, numba rescĩa ó libro de $A$. Figueroa, Diglosia e texto (1988). Mantel Forcadela referíase a esta actitude crílica, (pue interpreta a ausencia de referencias á cultura popular como un deterioro na consolidación (lo discurso literario galego (ANT, 375, I6-2-1989).

Que o novo discurso literario reivindicfue un maior grao de anorreferencialidade, en claro contraste con manilestacións anteriores. consideradas ala moi recentemente como paradigmáticass", evidencia tensións dentro do sistema literario e demostra a pervivencia en determimados sectores culturais dumb imaxe da literatura galegal, segundo a cal o canon estaría

10.- Sen embarge, nun suplemento cultural de Lat Voz de (jalicia (10-12-1981), aíndat se afimalba que "non ten posibilidades profesionatis o escritor galego". E X. Maure un ano mais tarde observaba gue "acpui len (jalicial nen hai escritores profesionais. non os pode haber, e non planifican a súa escritura (ensalios, novelas...)" (ANT 205, 5-12/11/1982). Unha ve\% máis ć necesarto aclatar que o reconecemento das múltiples dificultades coas (pue se enfientat a profesionalización do escritor galego non permite concluír a inexistencia dunha crecente antonomía do discurso literario galego.

11.- Pénsese nos múltiples esfor zos canonizadores que pesan sobre os ('antares reivindicativos de Rosillía de Castro, a narrativa testemuñal de Neira Vilas, ou o verso insurxente de Longa noite de pedra. 
representadlo exclusivamente por textos de temática social e rejvindicativa. Esste proceso de crecente autonomización do texto literario vai acompañalo doutro fenómeno non menos determinante: a adequisición por parte do espacio discursivo literario dunha independencia institucional con respecto a outros espacios sociais'.2. Con estal observación non estou suxcrindo que o expacio literario (o espacio no que se produce e organiza o (liscurso litcrario) esteal agora menos determinado polo conxunto das prácticas socias que caracterizan a sociedarle gatlega; polo contrario, a automatlización do discurso literario só pode ser explicado porque as institucións que definen ou delimitan esta fómula discursiva funcionan agora coa súa propia especificidade ó lado doutros espacios instifucionais (o xuŕlico, o educativo, o político, o relixioso, elc.), dialogando con eles e intervindo. dende a súa propia especificidade, na configuración da malriz discursiva social.

\section{Einfrontamento institucional}

A análise da institucionalización düun determinado ámbito discursivo, inclúdo o literanto, (lebe tomar como punto de partida o seguinte principio: "the especifically symbolic power to impose the principles of the construction of reality -in particular, social reality is a major dimension of political power» (Bourdieu. 1977: 165). A súa constatación faise máis notoria en situacionns caracterizadas por relacións de dependencia no control discursivo, o caso da sociedade galega. Paradoxicamente, esta condición privilexia a multifuncionaliclade do discurso literario, que cantiliza tódlalas representacións heterodoxas da realidade. O mesmo P. Bourdieu chama a atención sobre un enfrontamento cue ten obvias repercusions para unha análise institucional do discurso litcrario galego; segundo o sociólogo francés, os grupos marxinais cuestionan as normativals oficiais e delatan a súa arbitlaricdacle: polo contrario, os grtupos no poder defenden a súa lexitimidade (1977: 169). Fiste conflicto produce en situacións de dependencia cultural un aumento das tensións entre os axentes institucionais da ortedoxia oficial c os anti-institucionais, representados por tódolos grupos que, dende perspectivals ideolóxicas distintas, reivindican a nomalización da cultura clue eles representan. e por tanto a súa institucionalización.

Son múltiples os indicadores desta tensión na confrontación entre os dous sistemas literarios que actúan en Galicia, o de expresión galega e o que utiliza o castelán. As reaccións á concesión do premio «Na(dal» (|99) a Alfredo Conde, ou als sistemáticals acusacións de pseudogaleguismo a determinaldos escritores (Torrente Ballester e Camilo J. Cela, fundamentalmente) e premios (Premio de Narratival «Torrente Ballester», instituído pola Diputación de $\wedge$ Coruña) ${ }^{\prime 2}$, son algunhas das manifestacións desta permanente oposición entre os dous siscemas literarios que se disputan a hexemonía e o control da producción simbólica da sociedat de galega ${ }^{14}$.

12.- Palla P. Bourdieu, un dos primeiros socióloges da cultura en analizar a institucionalización dos discursos simbólicos: le degré d’aulonomie d’un champ de production restreinte se mesure á son pouvoir de produire e d'imposer les nomes de sal production et les criteres d’évaluation de ses propes produits. donc de retraduire et de rénterpreter toutes les délerminations externes conformément á ses principes propres (1971: 56).

13.- M. Riveiro Loureiro nun articulo titulado «lnha mención honorífica. Isscribir en galego, escribir en castelín» calilica de "hiade cultural» este premio (D)-16. 25-1-1992).

14.- Palla ver como se traduce no novo discurso narrativo galego a oposición entre a ortodoxia $c$ a heterodoxia, pode consultarse X. Gonzále/-Millán (1991). O paradigma polisistémico de Even-\%ohar (1990) 


\section{XOÁN (jONY,ÁL.F.7-MILLÁN}

A aludida utilización do discurso literario galego como instrumento reivindicativo permite comprender algunhas das dificultades que obstaculizan o seu funcionamento como un discurso autónomo. A lexitimación exclusiva dun enfocpue esencialmente temático e social. xunto coa obstaculización á entrada no sistema literanio galego de novas formas de representación (a novela policial e a erótica, cntre outrás manifestacións recentes), e a súa conseguinte perda de incidencia na institucionalización do discurso literario, representan algúns dos comportamentos que presupoñen afirnacións como a seguinte:

Do ponto de vista dos contidos - aproximación ao real sociolóxico- e do ponto de visla das formas - intelixibilidade, pensamento e sentimento, como expresión determinante-, o réalismo é o grande momento da cultura galega e lamén o elo caracterizador (Rodríguč, (9)(): 20$) 15$.

Fsta oposición a facer públicals (=imprimir) determinadas representacións literarias da realidade, e a instrumentalizar o galego para contïgurar mundos simbólicos cacla vez máis diversos, é unla forma de dificultar a recuperación c a lexitimidade da lingua conpregada, e de obstaculizar a institucionalización do sistema literario e do espacio discursivo que o sostén.

Fon relación con esta ampliación de formas, e coa superación dunha atrofia funcional, (lerivada en gran parte das circunstancias nas que se desenvolvía o discurso literario galego, os seus axentes (productores, distribuidores c consumidores) enfróntanse á tarefal de institucionalizar as novas experiencias literarias derivadas da cada vez máis obvia distinción entre unha producción simbólica limitadla e a dedicadla ó «gran público». Ala épocas moi recentes, para os estudiosos da literatura galega o criterio filolóxico do idioma empregado defińáa a calnonicidade dun texto; progresivamente ese criterio está perdendo forza lexitimadora, c está sendo sustituíclo por outros máis complexos, nos gue interveñen xuízos de valoración artística, ó laclo de criterios comerciais e sociais. A entrada do discurso literario en espacios sociais ata agora inaccesibles (universidade, ensino medio e primario, institucións políticass) th esixe unha nova formulación nos critcrios de institucionalización do discurso litcrario galego.

\section{4. leuncións institucionais: datos sobre un proceso.}

A partir de 1975, tódolos observadores da realidade cultural galega detectan un crecente nivel de consoliclación e diversificación das súas manifestacións. O literario, como se observa na creación e reflexión dos escritores máis novos, é un dos discursos cue experimenta unha maior transformación, distanciándose progresivamente da súa privilexiada, e difícil, situación na historia moderna de Galicia como instrumento de articulación e lexitimación dunha determinada ideoloxía nacionalista. Os comentarios literarios que Suso de Toro recolle en I.M. (1991) son reveladores dunha crecente vontade de rexcitamento a utilizar o discurso literario para consolidar determinados mitos colectivos. Moita cla crítica que se lle lai a esta noval literatura, especialmente descle detcrminados sectores nacionalistas, subliña concretamente a súa

permite analizar as conflictivals relacións entre sistemas literarios de desigual poder canónico. que é un (los aspectos maiis rekevantes na análise do complexo proceso de institucionalización (lo discurso literario galego.

1.5.- Subliñado no texto orixinal.

16.- O uso que as autoridades atuonómicas están a facer do discurso literario está emblematicamente representado pola conferencia de Fraga Iribarne (1990) na clausura do Congreso Internacional da Coultura Galegal (Simtiago, 27-10-1990). 
inoperancia reivindicativa e contestataria en comtraste cos textos máis representativos, desde Rosalía de Castro a Celso li. licreteiro' ${ }^{17}$.

As reflexións sobre a progresiva institucionalizacion do discurso literario non proliferan, sen cmbargo, nos medios intelectuais, a pesar dat crecente necesidade de analizar este lenómeno que se fai carla vez máis visible entre os indicadores da rápida transtormación (jue se está operando na sociedade galega. Aparecen, si, e de foma esporádica, algúns comemtarios sobre o tema, especialmente no semanario A Nosa Terra, que aproveita os números correspondentes ó mes de maio para ofrecer anualmente novas perspectivas críticas sobre a cullura, e máis concretamente sobre o feito literario. No I06 (16-22/5/8()), Fancisco (amballo firmabal un arlículo cun título moi revelador, "Cuturalismo e institucións culturais galegas", no (que ofrecía unha síntese deste espacio social e denunciaba «a tenlación culturalista no presente». No mesmo número transcribíanse as discusións (lunha mesa reclonda sobre a siluación da cultura galega, nas que saía a relucir a necesidade de profesionatizal a producción do mundo simbólico. X. Campos, un dos participantes, admitía que uo (la profesionalización é un problema real cla cultura»; e Bieito l.eclo, xerente entón da editorial Galaxia, recoñecía que «na cultura galega estamos ańnda na resistencia camiñando cara a nomalización». Estes son algúns dos datos que permiten documentar unha especial toma de conciencia, (pue xurde a principios dos 80, e que ten como obxectivo reflexionar sobre os desatíos da crecente institucionalización da vicla cultural galcgat.

No número 342 (17-5-1988) inclúcnse dous artículos: «l iteratura e poder institucional», de $\Gamma$. Rodrígue\%, e «Reflexións incompletas sobre a situación da literatura galega», firmato por X.M. Dobarro e C.P. Marlínez Pereiro. Ambolos dous traballos queren ser, desde perspectivas complementalrias, un diagnóstico do discurso literario na década dos 80, e especialmente, unha análise sobre o seu crecente proceso de institucionalización. F. Rodríguez identilica unla serie (le presupostos e prácticas culurais que afectarian de forma negativa, segunclo o articulista, o desenvolvemento do sistema literario) galego: a promoción artificial de uxéneros considerados próprios da literatura de consumo (novela policiaca. literatura infantil e novelas (le aventuras...)»"s; "a promoción (le aclividades culturais, que teñen un lonte soporte literario (revistas, encontros, clebates), con ostentación de vangardismo, modemismo ou modan; a proliferación dunha política de premios orientada a criar umba rede de clientelismo e amiguismo; c «a integración marxinal e acaclemicista do estudo da nosa literatura no sistema educativo». Fstas prácticas culturas, promovidas polas dilerentes institucións oficiais (literarias e políticas), conducen a "agudizar determinadas tendéncias, e a ocultar os graves problemas de fondo con que se topa a literatura galegas, (que $F$. Rodrígue\% enumera nos seguintes termos: a "problemática, cativa c crítica» relación da literatura galega coa súa sociedale; a persistencia das dificulades para unha representación de toelo o real na literatura galega; a "proliferación da poesía |... e especialmente dirixida a un círeo de leitores cualificados, indicativa da caréncia de proxectos sociais globais; |... | o reforzanento dos mecamismos

17.- X.M. Salgado caracteriza, e caricaturiza, esta tendencia interpretativa radical, a que non lle «interesal o manexo da palabra de Rosalía de (astro nin a maxia verbal que pode er un (éso Emilio nos seus versos: o único digno de comentar é o que de reivindicativo poida haber en (antares gallegos coma en I.onga noite de pe(brias (C (i, 2-6-|0)1).

18.- A partir de 1985 este tema vai converterse nunha das referencias obrigadlas para clasificar al creación c a crítica literarials galegals. Para uns trálase de ucscribir de lodo e escribir ben» (X.R. Pena, D-16, 2510-199(0); para outros uhoxe por hoxe. é unha certa contradición ser escritor galego e non ter, cando menos, unha conciencia cultural nacionalistas (F. Rodrígue\%, ANT, 342, 17-51988). que debería traducirsc, imaxínase o lector, nunha determinada selección temática. 


\section{XOÁN (IONLÁLLI\%-MIII.ÁN}

(le autorepresión no escritor» reflecticlo na falta de presencia dos conflictos reals da socieda(le galega na literaturat, especialmente ma movela e no teatro: e finalmente, a ausencia dunha crítica literaria «intelixente».

$\Lambda$ amálise de Dobarro e Martíney Pereiro suliña uns aspectos do discurso literario galego nos que os auteres detectan cambios profumelos e desafíos (jue está a vivir o sistema literario galego como institución: un culturalismo elitista, o reduciclísimo número de lectores, a preponderancia de literalturas foráneas, a ausencia de vontade instinucional e interés político, o recurso ó ensino como panacea do mundo editorial galego, e finalmente, a situación de manxinalidade do galegoo como lingua pública "." Con lodo, os autores do artícule condeden en sinalar "(pue hoxe a nosa literatura está institucionalizándo-se e conlomándo-se en élite»; este tendencia, continúan argumentando, hai que relacionala ucoa ampliación do exercicio da cs-

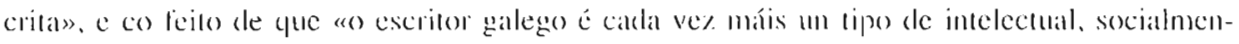
te o bastante numeroso para constituir-se en mercado de leitoress.

Fonte as funcións asignadas ás institucións literamiats, como en calcuera ontro tipo de organización, fignua en lugar privilexiado a protección dos individuos, neste calso tódolos aleenles yue se reparten o espacio (lo discurso literario, é dicir, escr itores, editores. distribuiclores. crílicos. e lectores. Festa primeira función é delectable munha serie de acontecementos (jue se producen a parlir do 3 maio de 1980, data ma que se reúne en Samtiago un grupo de escritores que acorela a constitución da Asociación de Liscritores en Lingua (jalega (AFiL(i), para (tefender, segundo comsla na acta fundacional. "os intereses da práctical escrita en galego»" Ela a primeira vez, na posguerra. (que un eolectivo de escritores (Paco Martín. Martíltez Oca e Méndey ferrín, entre outros) se constituía para represemtar e defender os intereses uprofesionaiss (lo escritor en lingua galega." Entre os obxectivos da AF. (j ligguraba, xa enlón, o laballar a prol da nomalización (o) feito litcrario $(C(; 1 / 5 / 199) 1)$. Lin maio de 1980 celébrase a primerra xuntanza (pue levaría a creación da ALLG. Un ano despois celébrase en Poio o "I (ongreso de Escritores en l.ingua Galegal», para reflexional, segundo Alfonso Pexegueiro, un (os seus organizadores, "sobre a situación da literatura e do escritor en (ialicia» (V(i 30)/4/ 1981); outros escritores consultados polo mesmo xornal mamifestan a necesidade de superar

19. Fronte a esta situación algúms grupos sociatis e políticos promoven, como fómula compensatoriat. deceminados xestos simbólicos: por exemplo, a inciativa de resvindical o recontecemente do idioma gatlego no Parlamento de Estrasburgo (c( $(\mathrm{i}, 18-9)-1991)$.

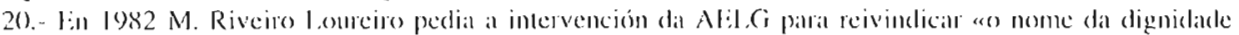

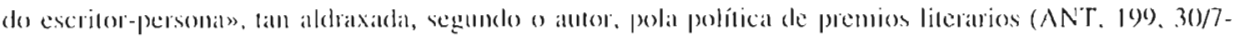

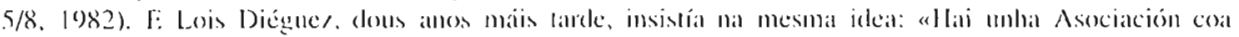
gue hoxe non se quere contalt, precisamente a mostución máis representatival dos escritores galegos, lanto

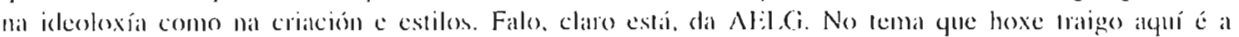

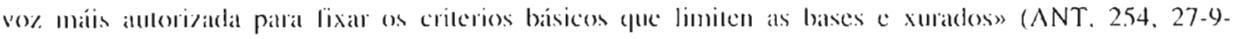
1984).

Non son alleas a este tipo de desallios as comunidlates de escritores españoles en castelán. En |979) celébranse tres congresos de escritores (Palermo. Almería e las Palmas), nos (fue se discuten problemas mois semellantes ós tratados pola AEL(il: a mova detincion do discurso litcrario, a reivindiciacion de perspectivas histónicas renovadoras para entendelo, a dimensión xurédicoprolesional dos dereitos dos escritores. e as conseguintes acesacions i Administración. Pode comsultarse J.M. Martíney Cachero (1985: 39()$-392)$.

21.- A primeira experiencia tivera lugar en 1936. () 30 de mar/o xúntase no satón de sesións do ConceIlo de Santiago a intelectualidade galega patia fundar unha "Asociación de Escritores de (ialicia". (que habia ter. entre outros obxectivos, o de "calegorizar o libor do escritor» galego (Salvador l orenzanta. 1983: 8). 
deteminadas actitudes elitistirs, e ude que se agrupen os escritores para defender a clase»: Rafael Dieste, pola súa banda, subliña un diato de especial relevancia, a "pouca socialibilidiade literaria»». Nunha entrevista concedicla a A Nosal Terra (318. 19-6-1987), o entón presiden-

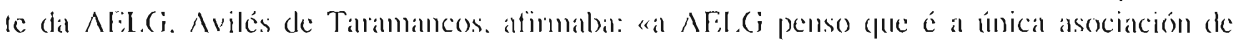
escritores yue vive e está presente no país. porgue a Academia non existe e está totalmente deslasadla». No mesmo número da publicación gáalega dílbase contia dun manilesto de escritores pertencentes á $\Lambda E L, G$, no (que se pedía a dimisión do presidente da Real $\Lambda$ cademia Galega (R.A.G.), o dector D. (iarcia-Sabell. F.ste acto viña confirmar por parte da Asociación de Fiscritores a vocación de protagonismo e de incidencia na vida social do país, presentándose como a "ontra) institución cultural galcea ". Tra un paso máis no dilïcil e complexo proceso de arriculación de institucionalización da imaxe social do escritor galego. Méndè. Ferrín. un (los firmantes do antedito manifesto, declanaría uns anos máis tarde: "A Real Academial en

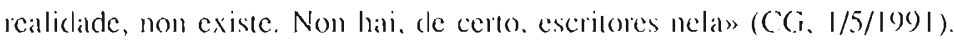

Outra asociación, o Pen Club (ialego, eral admitida nos seo do Pen Club Internacional durante o 5.3 (ongreso celebrato en Makastrich (Holanda). no mes de maio de 1989). Houbera (III intento anterior de solicitude en 1977. pero fora rexeitadlat ('Teima, 20). 1977). A noticia dia constitución desta noval agrupación de escritores suscitou, ho seu momento, comentarios de apoio e rexeitamento, nos cue se detectaban as fortes presións ideolóxicals a doue están someticliss organizatcións deste lipo en Gialicia (ANT. 389, 1-6-1989).

No Il Fincontro (ialcusca (4-6) de outubro, 1985) recoñecíase unlat problemátical común ós escritores galegos. valscoses e cattalíns. centrada na recuperación da nomalidade linguística e cultural, nas relacións cos poderes públicos, na lei de propiedade lntelectual, e na políticia de traduccións". As conclusións do encontro reflexaban tamén un fronte común, apoliade numla serie de definticións (a condición mesma de escritor galego, vaseo ou catailán), e de reivindicacións en tomo á consoliclación dunhas institucións capaces de arlellar a infraestructura necesaria para a clifusión e representación internacionais das literaturas respectivas en tóclolos ámbitos.

() seguinte Encontro (ialeusca, eetebrado en Santiage (18-19) novembro. 1989), sirveu lamén de plataforma á Al:L, ; para difundir un manifesto no (jue se lles lembraba ós medios de commicación a súa sbriga no espallamente e difusión da literatura galegal denunciábase todo atentado "contra os intereses xerais do escritor-al galegos»; criticábalse a inoperancia da R. A. Ci. e do Consello da Cultura; e a obriga que tiñan as institucións españolas de "ganantir $|\ldots|$ o exercicio dos seus direitos. expresannente os lingiísticos: eliminen, por tanto. das condicións para concederen axudas económicans caleśsuer de lipo ideolóxico, opinión política. escola literaria, estilo (le escrituras (AN', 409). 23-11-1989).

Se un dos obxectivos das institucións literarias se cifra na imposición de determinades sistemas de normas e valores. é dicir. no control dos procesos de socialización. é lóxico esperalr unha crecente institucionalización dal literattura galega nos diversos niveis educativos. Lُ este un ámbito no (pue a literatura galega comeza a intervir no espacio asignado ó discurso li-

22.- Da necesidade de consolidación dunha institución semellante dabiun idea unhas declanacións de $X$.

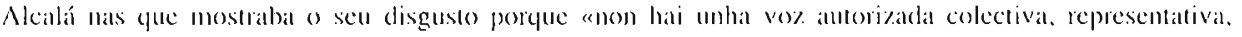
(jue se manileste en nome dos creadores» (ANT. 302, 23-10-1986).

23.- Neste mesmo ano. Alliedo Conde alimaba, munhal entrevisla a (ammen Parada, que uo diat que unha novela galega apareza traducicla ó inglés on ó francés será un día importante para (ialicia, os tempos nos que as novelas galegals aparecan nomalmente traducidas a outros idiomas serán tempos de fartura para (jalicias $(V(i, 1()-1-198.5)$. 
terarion na socialización infantil e xuvenil. Non pode csquecerse, sen embargo, que, aínda que as institucións son lugares de dominación e subordinación ideolóxicals a través dos cales se cxerce o poder, a condición de cultura marxinal impón determinadas limitacións ó exercicio institucional do espacio discursivo literario galego. Un exemplo facilmente constatable é o representado polo sistema educativo galego, que exerce un poder moi efectivo como institución icleolóxica, pero (que non lle permite ó sistema literario galego funcionar como tal, polas múltiples dependencias que obstaculizan esta función: a situación diglósical, a marxinación social do mundo simbólico galego, e a subordinación fronte a outro sistemal literario (o de expresión castelí). F.sta subordinación explica que a entracla da literatura galega nos plans (le cnsino non vaia acompañada, polo momento, da incidencia que deberia ter entre os diversos discursos simbólicos que actúan nas funcións de socialización do estudiantado. tendo en conta, como sinala A. Viala, que "l'inscription en discipline d'enscignement est lat plus efficalce légitimation social d'une activité intellectuefle» (1985: 1.37). A entrada (la literatural gallega no sistema educativo debería garantir a súa institucionalización definitiva, sen embargo os problemals persisten.

Neste senticlo, convén ter en conta algunhas dass áreals de interferencial entre a institución literaria e o sistena educativo: en primeiro lugar, o uso pedagóxico da literatura implica un proceso de socialización das normas de escritura, codificadas en determinadas obras literarials,

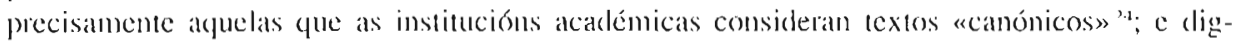
nos, por tanto, de ser incorporados nos manuais escolares. O mesmo tempo, e como parte deste proceso, a institución literaria é apropiada polas autoridades educativals para establecer unhals normas lingüísticas, yue son propostas como nodelo de lingua nacional. Fsta lunción está especialmente condicionadia, en Cralicia, pola siruación diglósica.

Como aparato ideolóxico a institución literaria carece hoxe do altactivo e dit efectividade cue posuía en décadas anteriores; pero esta nova situación non signilica, obviamente, a desideoloxización da producción literaria. Como afirma J. Dubois, nun comentario que resulta especialmente pertinente para situacións culturais como a galegal, "le corpus littéraire devient réservoir de symbols destinés à alimenter le discours social par un jeu d’emprunts»; sobre toxlo canclo «la splière littéraire alimente encore généreusement le discours général de ses images el des ses sy'mboles» (1978: 7.5).

\section{O escritor e os medios de comunicación:}

Ala ben entrada a década dos 70, a autonomía do escritor galego era máis unha condición innosta por unha situación de dependencia cpue un desexo, individual e colectivo, de practicar a liberdade da creación literaria. $\Lambda$ circulación dos textos reducíase practicamente á comunidade mesma dos escritores ${ }^{2 .}$. A clisposición da comunidade literaria a partir de 1975.

24.- A Sub-Direccion Xeral do Libro tiñal organizadlas, ata 1989, catro "Campañas de Fomento da I ectural» en centros de F.X. B.. polas que varios miles de estudiantes se beneficiaron de encontros con escritores. concursos e outras actividades. encamiñadas a axudarlles a descubrir o placer da lectura en galego. O mesmo kempo, estas campañas facilitaban a incidencia da literatura no sistema educativo, c apoiaball a institucionalización da literatura infantil e xuvenil, comsolidando a canonización de cenus textos, és seus autores.

25.- E. Blanco-Amor c X.L. Méndes I:errín, clous dos escritores máis representativos deste periodo, Lestificaban nas súas propias reflexións a incxistencia dun lector galego real. O primeiro, no seu famoso "Prólogo útil». recoñećía como udubidesa a esistencia mesma dos propios destinatarios, fora das notorias 
c máis concretamente na décalda seguinte, é distinta. Dende varios ámbitos sociais xurden voces que lle recomendan ó escritor unha maior inciclencia social, sobre todo a través dos medios de comunicación. Co título de "Escritores para un reto» publica L duis Alvarez Pousa un artículo (V(j, 6-11-1980), no que lle reclama ó escritor galego unha noval actitude social: «() labor calado (le moitos escritores tivo os seus hroitos nos tempos das sombras. E proseguirá. Pero chegou o momento do reto», que para o articulista se traduce en "proxectar o labor do escritor, o labor do intelectual, a traveso dos medios de comunicación», como estratexia encamiñada a unha maior elicacia do seu labor creativo. A cultura do libro, condicionada por unla distribución restrinxida no horizonte da moi limitada expansión do munclo editorial galego, tiña que ceder á cultura dos medios de comunicación, coas lóxicas transformacións na imaxe social do escritor\%. Non é anecdótico (jue Alvarce Pousa enfoxue o tema da súa proposta como vocal da primeira Xunta Directiva da AFi, G. Nesta mesma liña encaixan as palabras de Xavier Alcalá que. uns días antes de celebrarse o I Congreso de Fscritores en Lingua (jalega (24/5/1981), afirmibal que:

o máis importante é que se erga dunha vè unha vo\% decindo que non hai nada que facer se non temos en conta que a producción de palabras en grandes cantidades faise pola radio e a televisión; [...] [e que non se debía] saír do congreso sen unha delinición definitiva sobre a postura dos escritores sobre os medios de comunicación (VG, $30 / 4 / 81)^{2 \%}$.

Nun estudio revelador e polémico ó mesmo tempo, Margarita I.edo Andión, xomalista e escritora, reflexionaba ó remata da década pasada sobre as dificultades do diálogo entre a escrita literaira e os medios de comunicación galecos. () balance cra pesimista: «finalizadla a transición politica, estabilizada a fómula estatal biparticlaria como modelo a apoiar por parte dos Medios de Comunicación dominantes, os editores delimitan o campo do galegon, que se concreta, segundo a autora, no descenso do uso do idioma. na súa reconducción individualiLada (lo «articulista orgánico e achegado cando non para o máis niclio exotismo», ou para a «Cativa política» autonómical (1989: 372-73).

minorías e confirmantes escencións» (1972: 17). Pola súa banda, Méndez-férin á pregunta sobre a existencia dun lector en galego, responde: "Fu máis ben diría (que non existe» (Salgado e ('asallo, 1989): 2()6).

26.- Este novo contexto permite entender unhat enquisal de liancisco Alonso sobre os "hábitos e manías dos nosos escritores" (I)-16, 9-11-199()). () título, "Escribe vostede na bañeira ou prefire a mesiña do seu ordenador?", é un claro indicador da nova imaxe social que está proxectando o escritor galego a través dos medios de conunicación. Un articulo desta naturesa sería impensable hai dè anos. Para Andrés Amorós a siluación do escritor español, en lingua casselá, non é moi diferente: "como cuilquiera de sus colegas de Oecidente, el escritor español siente, hoy. que ha cambiado su papel social y político, en una sociediade posindustrial: se encuentra desorientado ante los avanees de lat técnicar. Vacila en su actitud ante los mass media, sin saber bien si cortejarlos o despreciarlos puritanamente |... |. Oscila también entre el horror ante lat rebelión de las masas y la búsqueda del best-seller. presendiendo que no le acuse de integrado pero tampoco de apolítico |... I. In general se replantea cuál es su nuevo papel social - si es que todavía posee alguno- en esta mucra sociedad (1987: 12).

27.- A revista Encrucillada, no seu número 23 (maio-xuño 1981), recollía algunhas das conclusións (lo congreso de Poio relacionadas co tema do escritor galego e os medios de comunicación: a esixencia de que os medios de commicación estatias empreguen o galego nos seus programas; que os medios galegos non reduzan a ghettos as seccións de cultura ou literatura gallegas; a creación dunha Facultade de Ciencias da Información no sistema universitario galego; e a reivindicación do deceito dos escritores en lingua galega a non seren traducidos ó castelán nas súas entrevistas. 


\section{Axentes sociais na producción literaria.}

Segundo Dubois, debe considerarse como axente institucional do discurso literario "un roulage institutionnel remplissant une fonction spécifiepue dans l'élaborattion, lat defintion on la légitimation d'une oeuvre" (1978: 82). A familial é un dos primeiros axentes sociais na institucionalización do discurso literario; este aspecto, sen embargo, carece dos estudios necesartios que permitan formular calcutera tipo de conclusión con respecto á literatura galega, anque non resulta disparalado imaximalr os niveis de autorrepresión que este espacio social reproduce, dada a siluación diglósica prevalente. O sistema xurídico, lexitimadtor, en última instanciar. dass diversas formas de censura, é outro dos axentes que intervén de forma determinante na institucionalización do discurso literario. Inexistente xal al censura directa. coa desalpartición do réxime franquista, persisten prácticas indirectas de silenciannento, traducidas nunhal determinada politica de subvencións "x. no dirixismo cultural, na selección de endencias. concesion de premios oficiais, e outras maniféstacións que falan de prácticals discriminatorias dende o poder. Fista política cultural non é. obviamente, exclusiva do ámbito gallego, como demostral Angel $\wedge$. Pérez (ióme\%, nun balance de (que ten side a cultura españolata ata 1985 (Reseña. 157. xullo-agosto 1985). e cue titulaba precisamente "Lal cultura española de hoy. Fintre la protección y el dirigismo». Como tódolos maios nos que as diversas publicalcións galegals ofrecen suplementes especiais sobre a cultura galegal. no número 341 de $A$ Nosal Tema (12-5-1988), podíase ler na primeina páxina a seguinte pregunta: “iQue fan coa nosal culurat?»; Nas páxinas interiores varios colaboradores (Guslavo I. uca de Tena. Manuel Veiga $c$ Xan Carballal) rellexionaban sobre o uclientelismo subvencionador» como substituto da política cultural; sobre o "difícil tránsito á modernización» da cultura galegal; sobre als interpretacións pesimistas e optimistas como formas de discurso dependente; e finalmente sobre a situación das "culturas periféricals ante a aduana estatal»-"."

Ademais dos axentes mencionados (a familia, o sistema xurídico e o económico), existen uns axentes especílicos, que aportan unha base concreta e aseguran a función evaluatival e lexitimadora. C.J. Valn Rees identifical tres institucións privilexiadas:

journalistic reviewers, essayists and academic erilics. Differences between them pertain to their different temporal positions vis-a-vis litcrary texts and to the valstness of the selection made from literary works of this century or of earlier periods (1983a: 397).

Pero o mesmo crítico recoñece pue a aceptación social deste proceso valorativo depende dunha serie de factores que, dende o punto de vista inslitucional, non son facilmente conceptualizables. ancue a súa efectividarle sexal incuestionable.

28.- Con respecte a este criterio, é unha experiencia bastante frecuente alopal en moitats das movelats re centemente publicalas a segumte nota: "() proxecto desta movela outorgóselle en fano| unha bolsa de

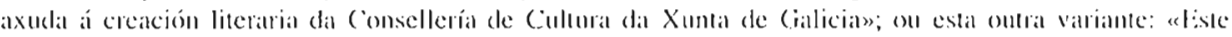

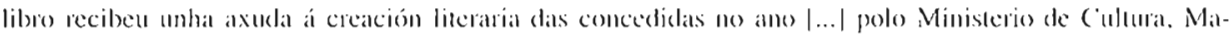
drids. Fste mecenado oficial non é interpretado, sen embango, polo escritor subvencionado como unha forma de elependencia. Valit como exemplo a reportaxe apareciela en l a Voy de (ialicia (24-9)-1989), na (que se dá conta da concesión de axudas a creación por parte da Xunla cle (jalicia. Algúns dos escritores entrevistades reiterabanlle ó xomal a sua absoluta liberdade con respecto ás institucións oliciais.

29.- A dimensión ecomómica deste proceso está protagonizada, fumblamentalmente, polo mundo editorial galego, que é un dos aspectos máis significativos no actual proceso de institucionalización do levito litelatrio. Xunto con outros aspectos relacionados con este mesmo fenómeno, é obxeclo de estudio numbal publicacion que en breve vali edilar Xerais de (jalicia. 


\section{A INSTITUCIONAIIZACIÓN DO DISCURSO LITLERARIO (IALLE(OO) (I97.5-1990)}

A décalda pasalda rexistra unha insólita proliferación de premios literarios "'. e dos órgatnos de prensal consigrados á crítica, é dicir, revistas e suplementos literarios en publicacións periódicans, como demosta un rápido inventario ${ }^{31}$. A explosión de revistas, culturais c literarials. na décadla dos $8($ ) significaba o reconecemento inslitucional dumba diversidade de discursos, de ideoloxíals, de proxectos e de formass de interpretar a cambiante realidade galego. Nun suplemento especial da revista I.eer (13, xun-set. 1988) dedicado a cartografiar o espacio literario galego, X.M. Alvarez ('áccamo calilicaba as revistas culturais c literarias galegas como "plataformas para captar remisos»: e observabal que:

si el campo de las revistas culturales gallegals estí hoy relativamente bien cubierto, en cambio el de las literarias muestra espacies vacíos que requieren ser completados con urgencia. Fallan en Galicia, y precisamente cuando está subiendo día a día el nivel de nuestra literatura de creación, revistas estables de poesía y crílica.

A vixencia das revistas de cultura e especializadas como instrumentos indispensables para consolidar a institucionalización do cliscurso literanto galego obsérvalse na vartiedade de intereses e proxectos de cada unha delas. Mannel Forcadela, nun dos suplementos de "Galicia Litcraria» publicatlos por Diartio I6 (14-6-19)(0)), recoñecíalles a estas publicacións «a función de soporte teórico explicativo deses textos fliterarios], unha función que poderíanos denominar crítical e. ao mesmo tempo, propagandística». F, por esta razón, concluáa o autor do artículo, poden ser interpretadas como un esigno da maior ou menor nomalidade da cultura de calqueta país». No mesmo suplemento, X.R. Pena entrevistaba al C. Casares. director de (irial, e a X.L. Méndez Ferrín, responsable de A Trabal de Ouro. A unhal pregunta sobre o espacio dedicado á crítica literamia en Grial, Casares era tallante:

Iso é algo que queremos consolidar, que sexal realmente sólido en Grial. Ffectivamente, unha boa revista ten de ter unha boa critica literaria. |... F. iso sobre tede, porejue desgraciadamente, non existen demasiados espacios entre nós $|. .$.$| para exercer a críti-$ ca.

A mesma preguntal cra contestada tamén por Ménde\%. Ferrín nos seguintes termos: «De todos os xeitos, a crítica literaria é esencial c, evidentemente, procuraremos abrir un bo canninoo para este apartaclo». Lista mesma necesidacle de abrir espacios á proxección críticar da literalura, e especialmente dia galegal cra expresada na presentación do primeiro núnero do BoIctín Galego de Literatura: «F, notorio (jue Gallicial carece aínda dunhal publicación adicada exclusivamente a acoller traballos de Análise. Crítica c Teoría litcrarias» (Tarrío, 1989): 5).

Pode falarse lamén da práctica inexistencia de escolas on tendencias literarias perfectamente delimitadas e efectivas como axencias institucionais; en parte, porque o escritor galego é consciente de que traballa nun sistema literario deficitario no que a función das tradicións

30.- Otro dos aspectos analizades na publicación anunciakla.

31.- Ala a segunda metade dos 70) a única revista cultural gallega cla a xal lexendiaria (irial (1951-). Norclés, revista de poesíi, xurde en 1975; no inverno de 1979 sale Bonaval (un só número), e logo, xal ben

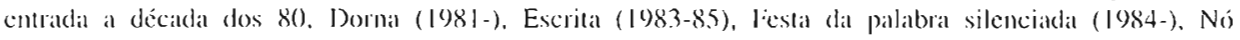

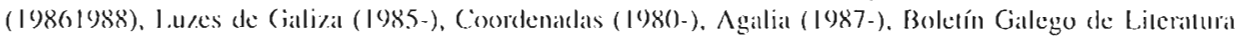

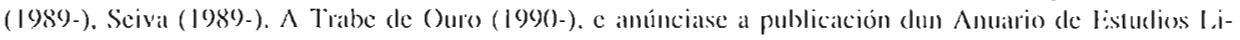
terarios Galegos para 1993. Fate inventario, ancpue incompleto, incopora as publicacións periódicas máis relevantes. É obrigado mencionar tamén os suplementos literarios. e seccións de cultura, dalgúns dos xornais galegos (lil Correo Ciallego. Diario 16. Faro de Vigo, La Vo\% de Galicia) e o semanario A Nosa Terra, que cubriron un espacio crítico, ata moi recentemente pouco e mal cultivado. 


\section{XOÁN GONZÁL.EZZ-MII.I.ÁN}

literarias apenas conta como principio de organización discursiva. () novo escritor galego, que se dá a coñecer na décacla clos 80, sinte unla maior tentación por abrir novos cspacios en cada un dos xéneros, e por distanciarse dun determiado pasaldo literario. Neste contexto, é necesartio aludir á ausencia de círculos críticos e á inoperancia da R.A.G. Lsta deficiencial é tanto máis lamentable se se ten en conta que unha das funcións prioritarias dos primeiros é aportar o recoñecemento de autores e obras, en tanto que institucións como a Academial da l.ingua deben consagrar ou lexitinlar as valoracións da crítica. A R.A.G carrece neste momen(1) da capacidade de lexitimación necesaria para apoiar operacións deste tipo, como documen-

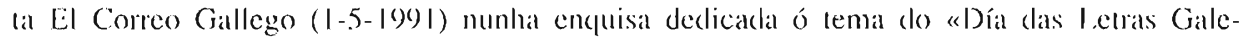
gals». P. García Negro era contundente nass súas declaracións: «Por parte oficial fo Dia das Letras (aalegas é unha celebración ritualizada para reservar o enaltecemento do galego, pero non a súa práctica c o seu uso para toda actividade no resto do ano». Obviamente, a efectivisade do 17 (le maio como proceso de canonización e de institucionalización do discurso literario galego segue dependendo da lexitimidade das institucións oficiais que o patrocinan "."

A desarticulación que caracteriza o exercicio da crítica literaria galega, prolagonizada, en gran parte, por esforzos individuais, c sen unha clara idea de programación colectiva, nin secquera no ámbito universitario, impide que o crítico incida máis activamente na intitucionalización do feito literario galego. O futuro da crítica literaria galega como institución debe facer lronte a unha serie de recos, que pasan por un proceso de vertebración apoiado na apartición de novas plataformas" e pola independencia con respecto ás diversas formacións ideolóxicas que mediaticen e comprometan o exercicio da críticat. como advitte en tono cartcalturesco J|osé| A[antón] M[artín]: «Fu creo que non só temos |en Cialicial críticos senón os críticos máis maravillosamente entusiasmábeis (le luuropa» (AN'1, 266, 29/3/1985), referínclose, sen dúbida, á "crítica dla amistade», como Xulián Maure caracterizara esta práctica uns anos antes (ANT, 205, 5-12/11/1982). Esta mesma descripción sería utilizada posteriormente por Manuel María: «tin canto á crítica sigo pensando que non hai crítica solvente, e o único que se fai é promoción de libros polos amigos do autor» (ANT, 328, 3-12-1987) ${ }^{4 .}$.

A ausencia de plataformas potenciadoras da crítica como axente institucional está perfectamente recollida por dous estudiosos da literatura galega, Anxo Tarríce e Carmen Blanco. O primeiro, en referencia á precaria difusión do libro galego, localizábala de forma case exclusival en "los suplenentos literarios de La Voz de Cialicia y" del Faro de Vigo. Qué duda cabe que no pueden recoger todas las críticas potenciales que puedan producirse en Cialicia. laaltan revistas especializadlas, revistas literarias propiamente dichals» (El Libro Lispañol, 30),

32.- Como dato especialmente significativo hai que sinalar un articulo-relato de Suso de Toro, publicado en $A$ Voz de (álicial, c logo recollido polo autor en F.M. no yue se parodia a festa literaria galega do 17 de maio, co título de «leliz no teu día» (199)1: 54-56).

33.- Xar observaba (.. Rodrígue\%. Fer (pue uat inexistencia en Galicia dunhas tribunats continuadas e inalterabeis que exeran o papel dun poder fático exprese no xuicio literario produce no profano na materia a sensación de c|uc al crítica litcrartia galega non existe» (V(j, 26-5-1983).

34.- Santos Alonso, referíndose ó mundo da crítica literaria xornalística no ímbito da literatura en castelán, sinala dúas posibles razóns para explicar esta nova actitude: en primer lugar, "sobre el crítico pesan demasiado los nombres de los autores y el escalafón de su prestigio; |... el amiguismo y disimuladas deudas entre autores y criticos que luego se transforman en invilacioness a lodo tipo de actos culturais, "loclos ellos remunerados espléneliclamente»; en segunde lugar, "a mayoría de los críticos en ejercicio. sobre todo de prensa diaria, tienen muy en cuenta el renombre y pocter de las editoriales". Para o autor do artículo estase dando entre editores e críticos unha uespecie de sociedad mancomunada en la gue los últimos son como intermediarios comerciales» (Reseña, 196, xuño 1989). 
1984); esta situación, en opinión de Carmen Blanco, semella non ter cambiado en 1990): «faltan canles se comunicación, o libro galego móvese se orella a orella, non hai unla crítica especializada, nin siquera un verdadeiro servicio de novidades que chegue finalmente ao público» (D-16, 20/9/1990). Se todo discurso social necesita, para a súa supervivencia, dun metacliscurso que o lexitime, é obvio que moitas das delieiencias do sistema literario galego débense á incxistencia ou á inoperancia dun corpus critico capar. de incidir, de forma activa, sobre a producción literaria mesma, e sobre a súa distribución e consunı.

A constante interacción entre a esfera da producción e a da lexitimación, é dicir, os múltiples casos de interferencia entre os escritores e as axencias instilucionais, é unha experiencia facilmente observable na realidade cultural galega, con obvias implicacións para o proceso de institucionalización do feito literario. Unha porcentaxe moi alta de escritores proceden do ámbito do ensino, e exercen como críticos, xurado nos premios literarios e/ou asesores de editoriais". Moitas veces obsérvalse que a condición de escritor facilita a entrada en estamentos públicos, como asesores ou funcionarios. () recoñecemento desta realidade e a constatación do reducido número de persoas dedicadas exclusivamente á literatura permite concluir que en Galicia os dous procesos, o da producción literaria e o da súa lexitimación e institucionalización, están estreitamente relacionados. E yue, por tanto, no espacio de proslucción do discurso literario tódolos clementos que contribúen, dunha forma ou outra, a esta institucionalización están sometidos a unha estreita interdependencia.

\section{7. () estatuto do escritor: a súa imaxe social.}

Moitos dos aspectos previamente sinalados apuntan a un cambio de imaxe do escritor galego, como axente colectivo e activo partícipe na institucionalización do discurso literario. Se o estaluto (lo escritor está relacionado coa posición que ocupa dentro do espacio social ocupado polo discurso litcrario, é lóxico que os cambios sufriclos por calquera clas axencias incidan nos demais. Cabe sinalar algúns dos factores gue interveñen de forma máis activa na definición da posición do escritor dentro do sistema literario.

En primeiro lugar, a formación, emerxencia e acceso ó poder simbólico do escritor; experiencias que en situacións de marxinalidacle, como a galega, adquiren unha especial problematicidade. Fin segundo lugar, as sempre complexas relacións interpersonais, condicionadas en parte por vencellos xeracionalis, pero sobre todo pola participación común nas diversas tarefas de reivindicación nacionalista. Outro factor relevante ten gue ver co(s) xénero(s) practicado(s), en relación co lugar que este(s) ocupa(n) dentro do sistema literario. As relacións do escritor coas diferentes axencias de produeción e lexitinación da institución literaria (a crítical, o mundo editorial, os medios de comunicación) constitúcn un apartado importante; así como as gratificacións e compensacións obticlas no curso (la biografía profesional. Finalmentc, na configuración da imaxe social do escritor galego pesan os manifestos estéticos, e a concepción mesma da escrita literaria. As xal mencionadas múltiples acusacións contra a literatura máis recente, sobre todo a que se publica a partir de 1985, á que se lle reprocha dende certos sectores da crítica un excesivo culturalismo hermético, denostran os cambios operados

35.- Nun encontro de escritores galegos e porlugueses (Santiago, setembro 1991), Alfredo Conde acusatba á escrita galega de ser unha literatura de profesoles para profesores; c Suso de Toro falaba do perigo de filoloxización que supón a alla porcentaxe de profesores/escritores (ANT, 489, 19-9-1991). 


\section{XOÁN (iONZ.ÁLEZ-MILIAÁN}

na diversificación (los rexistros do discurso literario, e a stía lóxica incidencia na imaxe social dos seus cultivadores.

Fn consonancia coas transformacións apuntadas, o escritor galego vese lomado a rellexionar sobre a súa propia concepción do leito literario, e sobre a condición do escritor nunha situación de marxinalidade histórica. Enganado só dous exemplos relativamente recentes, o de Manuel Forcadela e o de Margarita Ledo, por ser simtomáticos destas transformacións. Fsta última reflexiona, no raballo xa cilado (1989). sobre a condición do escritor galego como «opoñente» e vangardista. $\Lambda$ idea central aparece nidia na primeira páxina: «Nen a resistencia kolleitou a compromiso do escritor coa escrita, nen a literalura coxuntural poderá apañarse como referencia dominante da literatura opoñentes. (367) Para M. I.edo o prototipo do escritor galego segue a ser "o escritor (a nación, (...) o escritor organizador». (368) anque pesa sobre el a ameaza de substitución pola aparición do "escritor light», (376) que é o resultado dunha serie de factores cada vè máis perceptibles na década dos 8(): a nova imaxe (lo escritor «sen territorio, (...) sen universo cultural ou histórico concreto»; a «tendencia alo dominio dos códigos multinacionais-moi formalizados»; e "a pasividade na iniciativa da criación escrita» (368-69). A síntese proposta por M. I.edo deixa entrever as difíciles c contradictorias circunstancias que condicionan a nova inaxe social do escritor galego:

É certo que unha nova contradicción, nova c performativa contradicción, anda a estriaxar o corazón do escritor galego -cntendido como grupo social e teño para min que o seu comén é ese querer alaviarse de figurino-escritor, escrilor paral a representación; que é ese quererse moi profesional - mentres agacha que cómpre vivir de aulas míseras c noitébregas ; que é querer pegar un choulo para o Pen-Club á maxe da súa historia propia ou ese sisar, acó e acolá, por entre formularios de sucedo para a literatura de quioscpue (367-68).

Manuel looradela, escritor e crítico, é un dos membros da nova literatura que máis teñen reflexionado sobre os cambios na imaxe do escritor galego, sobre fodo na década dos 80 . A el débeselle unha ponencia moi significitiva, presentada no Congreso de Galeura ( $S$. de Compostela, novembro 1989), e logo publicada en A Trabe de (Ouro (1990)). Ancpue o tílulo, "O poeta na (ializa de hoxe», fai explícita referencia a un xénero deteminado, as suas conclusións son aplicables ó escritor galego en xeral. Parte da constatación dumba dobre crise: a da poesía como xénero, e a do seu «instrumento lundamental», a lingua. Se a primeira é unha condición compartida con outros moitos espacios culturats, a segunda describe as deficiencias propias das linguas marxinais. A combinación destas dúas encrucilladas obriga a Forcadela a preguntarse pola influencia do público, pola imaxe do autor, e polas ideas preconcebidas con respecto ós xéneros literarios; e lodo esto nun profundo cambio (le horizonte de expectativas comparticlo polo escritor e por un público, que a penas agora fai a súa aparición como ente colectivo. Velacpuí unha das observacións máis reveladoras desta nova concepción da escrita literaria gatega: «O cro consiste (...) en conlundir a vida cultural (lun país coa producción literaria propia» (77) º. Trátase dun cambio ladical na perepeción social do discurso literario, como evidencia o seu contraste cods declaracións que ańnda a principios dos 80 se seguían oíndo nos medios intelectuais galegos, en relación coa súa situación hexemónica sobre os demais discursos sociais, como recoñece o mesmo M. Forcadela canclo afir-

36.- Dende outra perspectiva, pero facéndose eco deste mesmo desalío, Manuel Regueiro, na súa condición de máximo responsáble da política lingiiistica da Xunta de (ialicia, ó formular o obxectivo do seu departamento, definía) nos seguintes termos: "Consiste sobre todo en non deixar ó galego comes un idioma exclusivamente de cultura. Hai que conquerir tamén que sexa un idiomal económico, filosófice, periodístico, científico, médicon (C:(j, 31-3-1991). 
ma que shistoricamente o escritor galego acadou unha boa palte do seu prestixio e dos seus lectores mercé á súa actitude radical en defensal do idioma e da cultura do seu país» (77) "2.

() novo estatuto (lo escritor galego asume unha serie de contradiccións que caracterizan a súa situación. Unha delas derívase da imposibilidade de que a práctical literaria poida fornecer do necesarto ó escritor galego. (ule se ve así obrigado a buscar unha segunda ocupación ${ }^{3 .}$. A función literartia pecha ó escritor no seu espacio discursivo, é esíxelle un alto investmento persoal: pero ó mesmo tempo éste oficio, e a situación é máis intensal cando está condicionalda pola marxinalidade cultural, non recibe o apoio institucional necesario, como demostran as súas dificultades para obter un mínimo recoñecemento social e xurídico.

\section{Conclusión.}

Convén recordar que a cultura galegal está nunha fase de transición, entre o voluntarismo que caracterizaba ata agora as súas empresas culturais e a estabiliclade que será conquerida unla ve\% aciadacla a normalidade institucional dos múltiples mecimismos que actúan nal producción sémica da sociedade galega. Lista transitoriedade, delerminada por moitas das contradiccións que loron xal simaladas, é perceptible na nova imaxe social do libro galego. O crecente control comercial do mundo editorial. e a tendencia a ver a producción cultural como śmbolo social de cambio, referente de moda ou simple signo externo de benestar. permiten adiviñar a transformación do libro galego en obxecto de consumo, e o seu graclual

37.- A rellexión de M. Forcadela anopon eco nal prensal galega. F, no no. 457 de ANT (13-12-1900) escribia Manuel Veiga un artículo titulado ePremios e lamentos na cultura do éxito imediato. As paladoxats do escritor galegon. no que salientaba as queixas inxustificadas de Forcadelat e dos escritores que estín representaclos pola sía rellexión, porque:

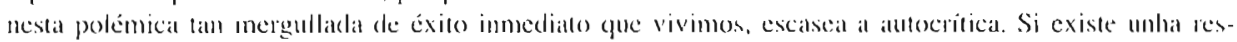
posta do públice galego deixando de mercar. por exemplo unha poesia tan hermética como é parte da (pre se esta a facer |... I. Escalsea lamén o interés do escritor polo segumento de enormes temas (jue prenanl a nosa sociedade e que poden quediat sen reflexo nas nosas letrats, mentres unha manchea de allores están dedicados a recriaren xéneros alleos, de antemano e sen se preocupar sefuer de reinterprelatos desde un ponto de vista proprio.

Con este tono de simpliticación carricalurizadora M. Veigal descentrabal unha necesaria intelección daigains dos problemas subliñades por forcadelat. A diversificación tensitica, por exemplo, que algúns críticos interpretan como unha actitude escappista, pode ser utilizada como un criterio para "reconnaître unc

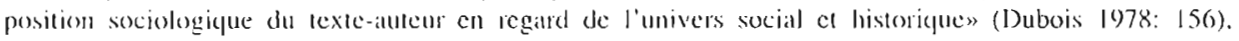
porque a Eemática no seu conxunto funciona como unha metáfora da posición do escritor na instllución literarial.

38. - A principios da década dos oitenta documéntanse moitos comentarios sobre a condición do escritor galego ucomo novelista de lin de semana, ou poeta dominical», expresións utilizadas por Basilio l.osada (V(i, 23-8-19SI): en termos semellantes se expresa X. Lois Taibo (AN'T, 163,6-12/11/1981). Nun suplemento cultural de $l$ a $V(o \%$ de (ialicia deste mesmo ano, no (que se inventariabal a produccion editorial gatlegal anual. presentábase unha imaxe nada optimista sobre as posibilidaden de profesionalización do escritor galego: "As demandas son cativas, escasamente esixentes, e por outra parte, a producción e comercialización do libro cada ves custa máis. Parellamente, a escasez de orixinais. Non len pessibilidades profesionais o cscritor galego. A nosa literatura scrá, xa que logo, de descanson (VG, 10-12-1981; subliñato meu). Comentarios semellantes emitían os escritores calaláns; o poeta Sala-Valldatura resumía a súa situación do seguinte xeito: "Antes diciase que os calaláns eran escritores dos demingos pola tardé. agora pode dicerse que somos escrimores de toclas as tardes. Iso é o que gañamos" (ANT, 274, 18-7198.5). 
control comercial e político. Estas dúas tendencias calracterizan a sublesenvolta infraestructura cultural galega, como (lemostraba un número monográfico do suplemento cultural «Arles e Letrals», do Faro de Vigo (26-5-1985), dedicado á «Industria cultural» gallega. () coordenador, José A. Perozo, iniciaba a serie de artículos declarando (pue ua definitiva normalización da cultura galega moderna pasa polo viciro do bon funcionamento dunha industria cultural potente e anovaclora»: para logo facerse as preguntas de rigor:

¿Lxiste en (ialicia unha inclustria cultural mínima? ¿Cal é a infracstructura coa que contamos c coa que contaremos cara ó porvir? ¿Estanse a chantar os medios para facermos da cultura galega unha realidade firme e con entidade?

A resposta era scmpre a mesma: "A cultura galega mantense nun ghetto testemuñal e amedrentado pola falla de empresals culturais serias con mentalidade modema». Neste mesmo número monográfico lirma un artículo Xulio Font, quen, ó lacer un repaso das indusirias culturais, observa «a gran distancia existente entre o pulo creativo gue hoxe vivimos en (jalicia e a súa escasa incidencia na sociedade». () título mesmo, "A casa polo tellado», constitúc, quizais, a mellor imaxe da insuficiencia institucional da cultura galega na décalda dos 80 . Un diagnóstico semellante é comparticlo polos primeiros balances da décacla clos 90 . nos que segue predominando un tono pesimista e pouco esperanzador. proba evidente de que os desafíos e obstáculos seguen aí, esixíndolles ós axentes institucionais do discurso literario galego un esfor\%o de imaxinación crítica e crealiva.

\section{Bibliografía}

Amorós, Andrés. 1987. Introducción: una clécada de literatura cspañola. Fn I elras españolas 1976-1986. Madrid: Castalia.

Angenot, Angenot. 1984. Gilossário da crítica contemporânea L isboa: Editorial Comunicaçầo. Benneu, Tony. 1990). Outside Litcrature. I.ondres: Routledge.

Blanco-Amor, Ĺduardo. 1972. «Prólogo útil». Lin Xente an Ionxc. Vigo: Cialaxia, 1972.

Bourdieu, Pierre. 1971. Le marché de biens symboliques. L.'Année Sociologicuue 22: 49)-126.

Bourdieu, Pierre. 1977. Oulline of a Theory of Practice. Cambridgc: Cambridge Univ. Press..

Bürger, Peter. 1983. Litcrary Institution and modernization. Poctics 12: 419433.

Dubois, Jacques. 1978. L.'institution de la littérature. Introduction à une sociologie. Brussels: Nathan-L abor.

Even-7,ohar, Itamar. 1990). Polysystem Studies, número monográfico de Poetics Today 11, 1. Figueroa. Antón. 1987. Diglosia e tex10. Vigo: Xerais.

Forcadela, Manuel. 1990). O poeta na Galizal de hoxe. A Trabe de Ouro. 1: 7.3-78.

Foucaul, Michel. 1971. L'Ordic du discours. París: Ciallimardo.

Fowler. Roger (ed). 1990. A Diccionary of Modern Critical Terms. L.ondres: Roulledge.

Fraga Iribarne, Manuel. 1990. A cultura galega: pasado, presente, futuro. Santiago de Compostela: Xunta de Calicia.

Gonzále»-Millán, Xoán. 1991. Silencio, parodia e subversión. Vigo: Xerais.

l.eclo Anclión. Margarita. 1989. Fscritores en lingua galega: opoñentes, orgánicos, mediáticos. Cuadernos Interdisciplinarios de Estudios L itcrarios Vo.1, no.2: 367-76.

Marlínez. Cachero, José M. 1985. I a novela española entre 1936 y 1980. Llistoria de una aventura. Madricl: Castalia.

Moisan, Clément. 1987. Qu'est-ce que I’histoire litteraire'? Parlís: Pur. 
Rees, C.J. van. 1983. Advances in the Empirical Sociology of Literature and the Alts: The Institutional Approacl. Poctics 12: 28.5-310.

Rees, C.J. van. 1983a. How a Literany Work Becones a Masterpiece: On the Threefold Selection Practised by Literary Criticism. Poetics 12: 397-417.

Rodrígue\%, Francisco. 1990). Literatura galega contemporánea (Problemas de método e interpretación). Pontevedra: Do Cumio.

Salgado, Xosé M. c Casado. Xoún M. 1989. X. I.. Méndez. Ferrín. Barcelona: Sotelo Blanco.

Salvador Lorenzana (Fernández del Riego, Rrancisco). 1983. Unha asociación de escritores galegos malogradia. Fiscrita 1: 8.

Tarrío Varcla, Anxo. 1989). Presentación. Boletín (ialego) de Literatura 1: 5-6.

Toro, Suso de. 199) F. F.M. Santiago: P'ositivals.

Vernier, France. 1974. L écriture et les Textes. Essai sur te phénomene littéraire. París: Eddilions Sociales.

Viala, Alain. 1985. Naissance de l’écrivain. Sociologie de la littérature à l’âge classique. París: Fid. de Minuit. 